\title{
Mutual Funds and the U.S. Equity Market
}

Eric M. Engen and Andreas Lehnert, of the Board's Division of Research and Statistics, prepared this article with the assistance of Richard Kehoe.

Mutual funds have become an important intermediary between households and financial markets, particularly the equity market. By providing liquid, lowcost shares in a diversified portfolio of financial assets selected by professional money managers, mutual funds have enabled an increasing number of households to enter financial markets. Indeed, about half of all U.S. households currently own shares in a mutual fund.

Since 1990, total mutual fund assets have increased nearly sevenfold, and the assets of mutual funds that invest in stocks have grown even more, expanding nearly twentyfold. Over the same period, mutual fund assets have come to account for a larger share of household wealth. Moreover, a greater proportion of U.S. households now own stock, in large part because of their investments in mutual funds. Much of this growth has come in households' retirement assets, as developments in pension plans and other taxpreferred retirement accounts have increasingly made it possible for households to control more of their retirement asset portfolios-and households have tended to invest a significant portion of their retirement assets in mutual funds.

As the popularity of mutual funds as an investment vehicle has grown, so too has their importance in financial markets. Mutual funds currently hold about one-fifth of publicly traded U.S. corporate equities. Thus, the investment behavior of mutual fund shareholders could, in theory, influence equity market prices. For example, if fund shareholders were to request large redemptions from their accounts when faced with a sharp decline in equity prices, mutual fund managers might be forced to sell some of the funds' equity holdings in the slumping market, exacerbating the decline. In recent years, however, mutual fund shareholders as a group have not tended to flee from their equity investments when confronted with sharp temporary drops in equity prices. Indeed, there is some evidence that shareholder restraint in requesting redemptions has been greater recently than during earlier periods of market turbulence.
Mutual fund investors could also distort equity prices if their enthusiasm for investing in mutual funds were to go beyond general market assessments of fundamentals and tolerance for risk, pushing equity prices temporarily above the level that other equity market participants would tend to settle on. We present evidence, however, indicating that mutual fund investors, like other market investors, have been trading primarily in response to new information and other factors that influence the value of stocks. Thus, in general, we find little evidence that mutual fund investors have been a destabilizing force in the U.S. equity market in recent years.

\section{GROWTH OF MUTUAL FUND ASSETS}

Assets under management at mutual funds have grown substantially over the past fifteen years (chart 1). ${ }^{1}$ At the end of August 2000, mutual funds

1. This article focuses on registered investment companies that are called mutual funds or open-end funds and excludes from the discussion other types of registered investment companies such as closedend funds, unit investment trusts, and exchange-traded funds. For more discussion of the mutual fund industry, see Phillip R. Mack "Recent Trends in the Mutual Fund Industry," Federal Reserve Bulletin, vol. 79 (November 1993), pp. 1001-12; Robert Pozen, The Mutual Fund Business (MIT Press, 1998); Investment Company Institute, Mutual Fund Fact Book (ICI, 2000); and Brian Reid, "The 1990s: A Decade of Expansion and Change in the U.S. Mutual Fund Industry," Investment Company Institute Perspective, vol. 6 (July 2000).

\section{Assets of mutual funds, January 1984-August 2000}

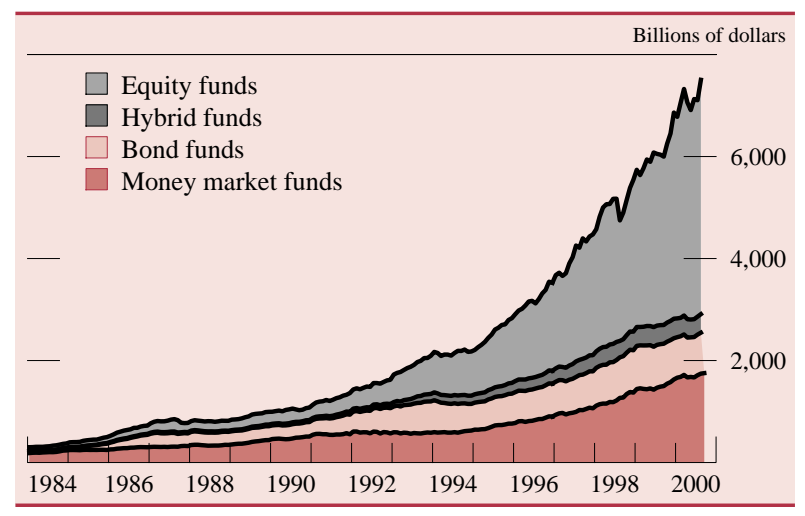

NoTE. Data show month-end assets.

Source. Investment Company Institute. 
2. Assets of equity mutual funds, January 1984-August 2000

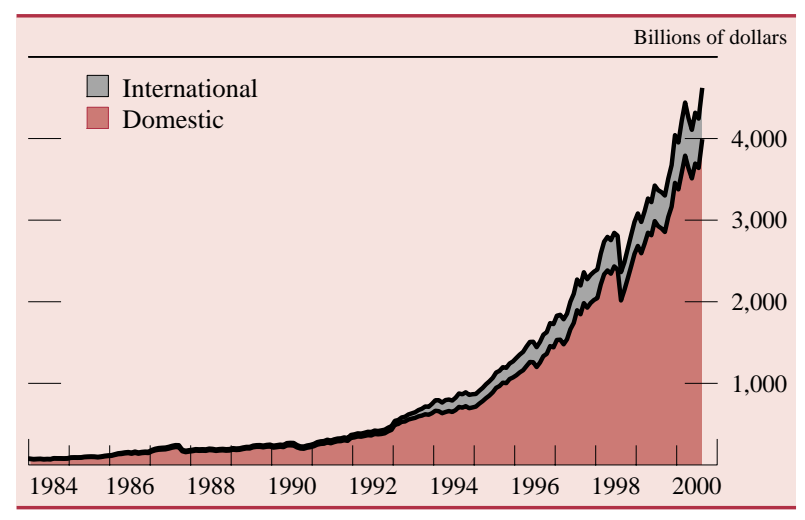

Note. Data show month-end assets.

SourCE. Investment Company Institute.

held about $\$ 71 / 2$ trillion in assets, making them the largest type of financial institution (as measured by assets under management), even larger than commercial banks. Most of the recent growth has come in assets invested in equity mutual funds, that is, mutual funds that specialize in investing in the shares of publicly traded firms. At the end of August 2000, equity funds held more than 60 percent of all mutual fund assets, or more than $\$ 41 / 2$ trillion. The next largest group-money market mutual funds, which invest in very short term liquid assets such as commercial paper and Treasury bills-held less than $\$ 2$ trillion in assets. Bond funds-which invest in corporate, Treasury, government agency, and foreign bonds-and hybrid funds - which invest in a mix of stocks and bonds-held about $\$ 1$ trillion in assets combined. ${ }^{2}$

Mutual funds that invest primarily in the shares of corporations based in the United States are by far the largest type of equity mutual fund (chart 2). These domestic equity funds hold more than 85 percent of the assets of all equity mutual funds. International equity funds, which invest primarily in the shares of non-U.S. companies, account for the remainder.

In 1999, 81 percent of total mutual fund assets were held by households. ${ }^{3}$ The remainder were held by institutional investors-businesses, fiduciaries,

2. Modern mutual funds were introduced in 1924. Equity funds were the most popular type of fund until 1979, when the assets of money market funds surpassed those of equity funds. Money market funds dominated equity funds throughout the 1980s, and by 1985 , bond fund assets had also grown beyond those of equity funds. It was not until 1993 that equity funds regained their current position as the largest type of mutual fund.

3. See Investment Company Institute, Mutual Fund Fact Book, p. 41. Household holdings include mutual funds held in retail accounts, employer-sponsored pension plan accounts, individual retirement accounts, and variable annuities.
3. Net new cash flows to mutual funds, 1990-2000

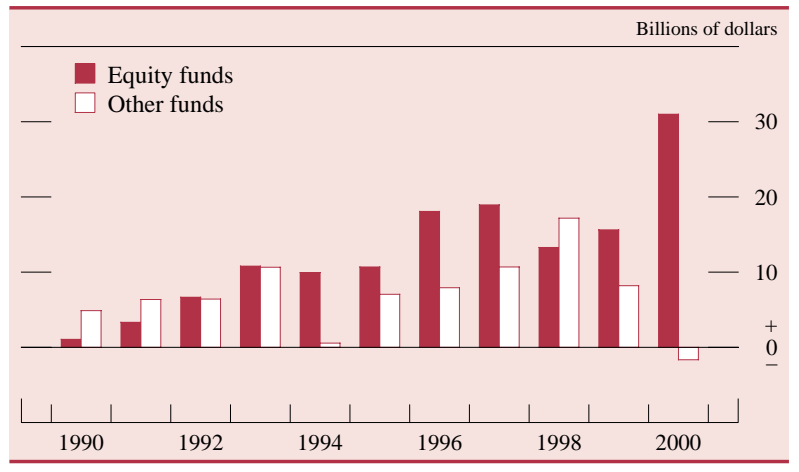

NoTE. Data show average net monthly flows excluding reinvested dividends for the year indicated; for 2000, values reflect flows through August. "Other funds" are hybrid, bond, and retail money market mutual funds. SourCE. Investment Company Institute.

and other organizations. Institutional investors are much more likely to invest in money market funds than in long-term funds (equity, hybrid, and bond) and at the end of August 2000 held less than 10 percent of the assets of equity funds. Thus, almost all mutual fund assets invested in the equity market are owned by households. ${ }^{4}$

Mutual fund assets grow because investors, on net, decide to put more of their financial assets into mutual funds or because the underlying financial securities held by the funds increase in value, or a combination of these two factors. Over the 1990s, total mutual fund assets grew at an annual rate of more than 21 percent. ${ }^{5}$ More than half the growth came from fund performance, that is, from the net appreciation in value of the securities held in the funds and from the reinvestment of dividends and interest earned by the securities held in the funds. Mutual fund performance has been robust in recent years, primarily because equity funds have benefited from the stock market boom. Net new cash flows accounted for 40 percent of mutual fund asset growth over the 1990s. ${ }^{6}$

Recently, average monthly net new cash flows into mutual funds have been dominated by flows into equity funds (chart 3). Since 1994, net new cash flows from households into equity funds have greatly outpaced those into all other types of mutual funds

4. In contrast, approximately 40 percent of money market fund assets are held in institutional accounts, with the remainder in retail accounts. The share of money market fund assets held by institutional shareholders has increased greatly in recent years, as many businesses and other organizations have decided that having their liquid assets managed by mutual funds is more cost effective than managing them internally.

5. See Reid, "The 1990s," p. 2.

6. Ibid. 
4. Net new cash flows to equity mutual funds, 1996-2000

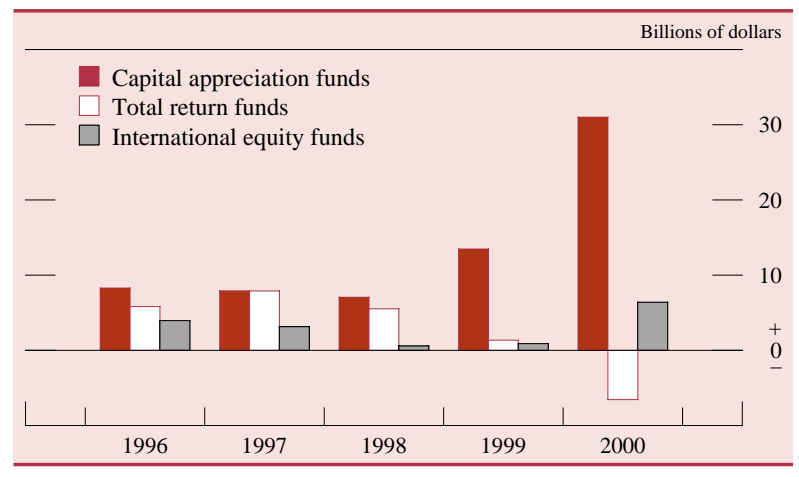

NoTE. Data show average net monthly flows excluding reinvested dividends for the year indicated; for 2000, values reflect flows through August.

SourCE. Investment Company Institute.

combined in all years except one. The Asian financial crisis and the Russian debt default prompted a "flight to safety" in 1998, and mutual fund investors reduced their investments in stocks and increased their investments in lower-risk money funds and short-term bond funds. That episode proved to be only temporary, and mutual fund investors returned vigorously to equity funds, increasing the pace of net new cash flows into those funds to a record level over the first eight months of 2000. Over the same period, however, households were, on balance, net sellers of directly held equities. ${ }^{7}$ Thus, at least part of the cash flows into equity mutual funds may represent a shift in household preferences toward holding a smaller portion of their equity portfolio in directly held stocks and a larger portion in indirect holdings via equity funds. ${ }^{8}$

In recent years, the flow of net new investment into equity funds has been greatest for domestic equity funds, with a much smaller flow going into international equity funds. From 1996 to 1998, net new investment in domestic equity funds was split fairly evenly between capital appreciation funds-which hold stocks whose return is mainly from capital gains-and total return funds-which hold stocks that return a mix of capital gains and dividend income (chart 4). In 1999, however, the pace of net new flows into capital appreciation funds picked up substan-

7. See Federal Reserve Board, Flow of Funds Accounts of the United States (Z.1 statistical release), September 2000, table F.100, p. 16. From 1995 to 1999 , households, on net, sold an average of about $\$ 329$ billion worth of directly held corporate equities annually. In the first half of 2000 , households sold, on net, $\$ 513$ billion of directly held corporate equities, at an annual rate.

8. Indirect equity holdings include holdings through mutual funds and also through employer-sponsored defined contribution accounts, personal trust accounts, and annuity accounts at life insurance companies.
5. Change in equity indexes, January 1996-August 2000

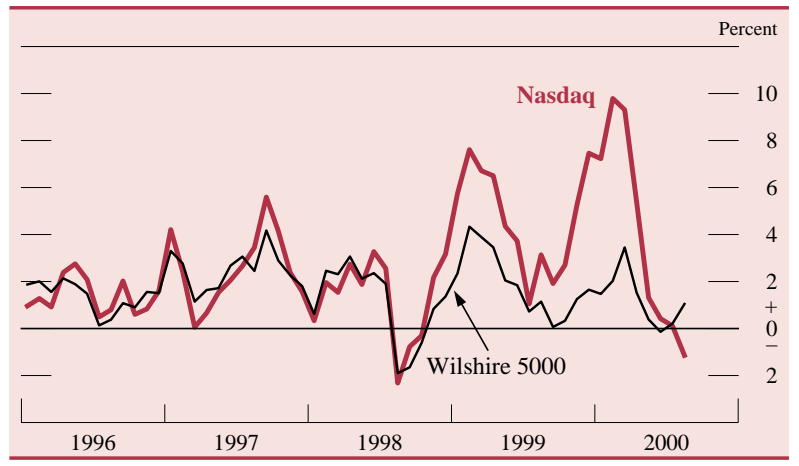

Note. Data show the six-month moving average of the monthly percentage change in the indexes.

tially relative to both the pace of the preceding few years and the pace of flows into total return funds, which fell off appreciably. Through August, net new flows into capital appreciation funds in 2000 were at a pace more than twice that of 1999 , whereas total return funds experienced net outflows.

Over the same period in which the composition of equity fund flows was shifting, the relative share prices of technology firms were booming. From late 1998 until mid-2000, the six-month moving average of increases in the Nasdaq composite index, which is dominated by technology firms, was markedly greater than the increases in the Wilshire 5000 index of the total stock market (chart 5). Capital appreciation equity funds are more likely than total return equity funds to hold the shares of technology companies. ${ }^{9}$ Thus, households were directing more of their net new investment into capital appreciation funds, which hold a greater share of their portfolio in technology stocks, at the same time the share prices of technology firms were generally outperforming the share prices of other publicly traded firms.

The volatility of equity prices has also increased recently (chart 6). Greater equity price volatility, everything else constant, might be expected to temper risk-averse households' appetite for equity mutual funds. However, not only did domestic equity fund flows accelerate through August 2000, but they were increasingly targeted toward relatively riskier capital appreciation funds.

Taken together, these developments might suggest that there is a relationship between equity fund flows

9. Using the most recent data available on mutual fund portfolios collected by the Morningstar data service, we calculate that, on an asset-weighted basis, capital appreciation funds hold an average of about 40 percent of their assets, and total return funds about 20 percent of their assets, in the stocks of technology companies. 
6. Equity market volatility, January 1996-August 2000

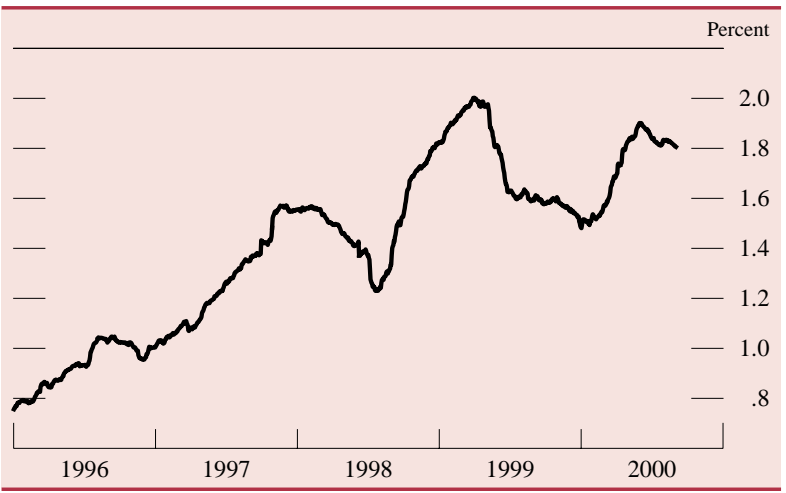

NotE. Data show the six-month moving average of intra-day swings in the S\&P 500; swings are calculated as the difference between the intra-day high and low as a percentage of the intra-day low.

Source. Authors' calculations using data from Standard \& Poors.

and equity prices. Such a link would depend on the role mutual funds play in household finances. Therefore, we turn our attention to the influence of mutual funds on the level and flow of household assets, the types of households most likely to hold mutual funds, and the purposes for which mutual funds are held.

\section{MUTUAL FUNDS AND HOUSEHOLD ASSETS}

The share of households' financial assets kept in mutual funds roughly doubled over the past decade, approaching 20 percent at the end of 1999; nearly all the increase was in long-term funds (chart 7). Domestic equity funds accounted for most of the increase in long-term funds, both because their assets appreciated at a greater rate than most other financial assets

7. Mutual fund assets as a percentage of gross household financial assets, 1984-99

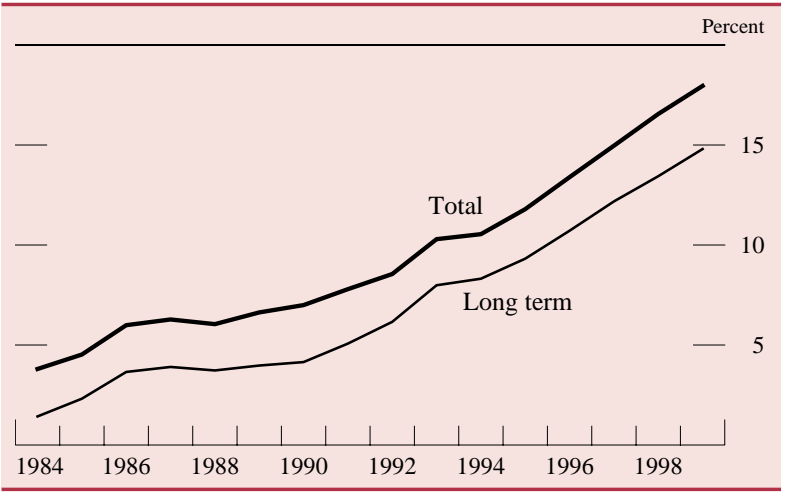

Note. Data show end-of-year values and include direct and indirect holdings of mutual funds. Long-term funds include all equity, hybrid, and bond funds and exclude money market funds.

SOURCE. Flow of funds accounts and the Investment Company Institute. and because they became the preferred type of fund for new mutual fund investments.

Net additions to household wealth, as measured by the U.S. personal saving rate, have declined dramatically over the past fifteen years, even as the popularity of mutual fund investing has grown. ${ }^{10}$ As a result, the share of household saving done through mutual funds has been rising. The share of gross financial saving-households' acquisition of financial assets, net of capital gains - allocated to mutual funds rose from about 15 percent in 1985 to about 70 percent in 1999 (chart 8). ${ }^{11}$ If this trend continues, mutual funds will represent an increasing share of households' financial assets over time, even if the performance of mutual funds is equivalent to that of households' other financial assets.

Mutual funds' share of aggregate household financial assets has grown in part because an increasing percentage of U.S. households are investing in mutual funds. In June 2000, an estimated 50 million households, or about half of all U.S. households, owned shares in at least one mutual fund (table 1). ${ }^{12}$

10. After averaging around 9 percent from 1950 through 1985 , the U.S. personal savings rate has fallen to lower than $1 / 2$ percent in 2000.

11. The Federal Reserve Board's flow of funds accounts calculate personal saving in several ways. One measure is households' net acquisition of financial and housing assets less their increase in liabilities. Gross financial saving, which excludes the acquisition of housing assets and liabilities, is the component of this measure of personal saving that is most relevant to households' mutual fund decisions.

12. In 1984, fewer than 12 percent of all U.S. households owned shares in a mutual fund; by 1992, the proportion had grown to 27 percent. See Investment Company Institute, "U.S. Household Ownership of Mutual Funds in 2000," Fundamentals, vol. 9 (August 2000), p. 1.

8. Mutual fund acquisitions as a percentage of gross household financial saving, 1984-99

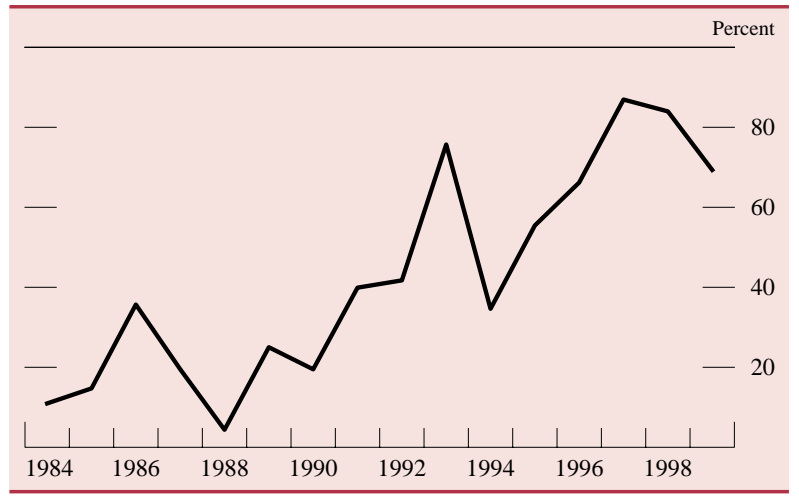

Note. Data show end-of-year values and include direct and indirect acquisitions of mutual funds. Gross household financial saving is defined as the net acquisition of financial assets over the year; it excludes capital gains and any increase in liabilities over the year.

Source. Flow of funds accounts and the Investment Company Institute. 
1. U.S. households owning shares in a mutual fund, by household characteristics, June 2000 Percent

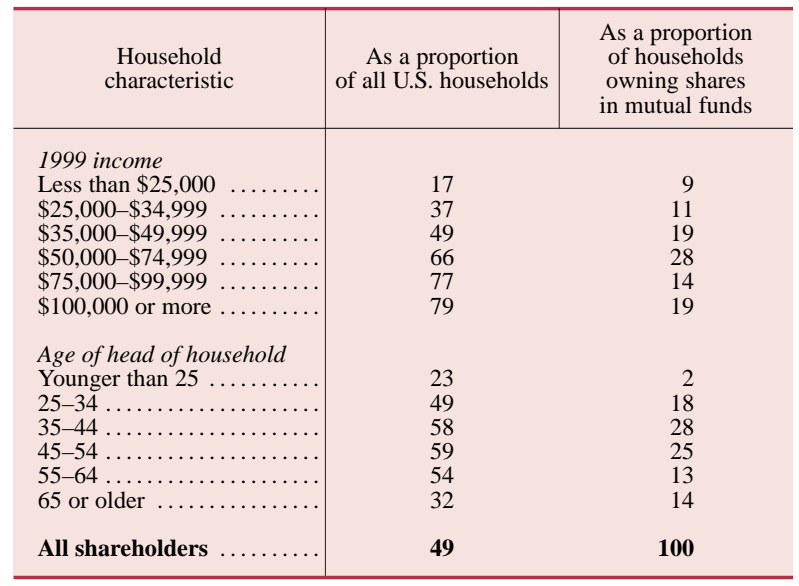

Source. Investment Company Institute.

Higher-income households are more likely than lower-income households to have financial assets, and they have greater financial asset holdings. ${ }^{13}$ Thus they are also more likely to own mutual fund shares. Nevertheless, mutual funds provide access to financial markets for households at all income levels. Indeed, almost 40 percent of mutual fund shareholders have an annual household income of less than $\$ 50,000$. Investors who have relatively low levels of income and financial assets generally find investing directly in stocks and bonds more difficult because of high minimum investment requirements and higher fees for small investments. Thus, mutual funds offer a relatively low cost means of holding a diversified portfolio of financial instruments. And because lower-income households may be less financially sophisticated than higher-income households, they may benefit more from the professional moneymanagement services provided by mutual funds. ${ }^{14}$

The likelihood of owning shares in a mutual fund peaks between the ages of 45 and 54, when most heads of household are working, and declines at later ages, when a greater proportion have retired. This pattern may reflect, at least in part, the importance of mutual funds for retirement saving. Because relatively widespread acceptance of mutual funds as an

13. See Arthur B. Kennickell, Martha Starr-McCluer, and Brian J. Surette, "Recent Changes in U.S. Family Finances: Results from the 1998 Survey of Consumer Finances," Federal Reserve Bulletin, vol. 86 (January 2000), table 5, pp. 10-11.

14. Dean M. Maki, "Portfolio Shuffling and Tax Reform," National Tax Journal, vol. 49 (September 1996), pp. 320-21, for example, presents evidence that lower-income households may be less financially sophisticated than higher-income households.
2. Proportion of U.S. households owning shares in a mutual fund, by household characteristics and type of fund, June 2000

Percent

\begin{tabular}{|c|c|c|c|c|}
\hline $\begin{array}{l}\text { Household } \\
\text { characteristic }\end{array}$ & $\begin{array}{l}\text { Equity } \\
\text { fund }\end{array}$ & $\begin{array}{l}\text { Hybrid } \\
\text { fund }\end{array}$ & $\begin{array}{l}\text { Bond } \\
\text { fund }\end{array}$ & $\begin{array}{c}\text { Money } \\
\text { market } \\
\text { fund }\end{array}$ \\
\hline 1999 income & & & & \\
\hline Less than $\$ 35,000$ & 13 & 4 & 6 & 9 \\
\hline$\$ 35,000-\$ 49,999$ & 33 & 11 & 14 & 26 \\
\hline$\$ 50,000-\$ 74,999$ & 46 & 15 & 20 & 32 \\
\hline$\$ 75,000-\$ 99,999$ & 60 & 24 & 28 & 39 \\
\hline$\$ 100,000$ or more & 68 & 27 & 31 & 44 \\
\hline Age of head of household & & & & \\
\hline Younger than $25 \ldots \ldots \ldots$. & 14 & 2 & 7 & 8 \\
\hline $25-34 \ldots \ldots \ldots \ldots$ & 33 & 10 & 12 & 23 \\
\hline $35-44$ & 44 & 12 & 17 & 26 \\
\hline $45-54$ & 42 & 16 & 20 & 30 \\
\hline $55-64 \ldots \ldots$ & 37 & 15 & 17 & 29 \\
\hline 65 or older & 21 & 11 & 14 & 19 \\
\hline All shareholders & 35 & 12 & 16 & 24 \\
\hline
\end{tabular}

Source. Investment Company Institute.

investment option is still a rather recent phenomenon, this pattern may also reflect generational factors. Younger generations, which have grown up with a well-established mutual fund industry, may be more willing to invest in these funds than older generations, which grew up less familiar with market investments and more likely to rely on bank deposits and insurance contracts.

Equity funds are the most popular type of mutual fund, with more than one-third of all U.S. households owning shares in such a fund (table 2). Indeed, for each income and age group, more households invest in equity funds than in hybrid, bond, or money market funds.

The percentage of households that directly or indirectly own stock in publicly traded companies increased dramatically over the past decade, rising from fewer than one-third of all households in 1989

3. Proportion of U.S. families holding stock directly and indirectly, by family income, 1998

Percent

\begin{tabular}{c|c|c|c}
\hline Family income & $\begin{array}{c}\text { Direct } \\
\text { or indirect } \\
\text { stock holdings }\end{array}$ & $\begin{array}{c}\text { Direct stock } \\
\text { holdings outside } \\
\text { of retirement } \\
\text { accounts }^{1}\end{array}$ & $\begin{array}{c}\text { Memo: } \\
\text { Stock holdings } \\
\text { as a share } \\
\text { of group's } \\
\text { financial assets }\end{array}$ \\
\hline Less than $\$ 10,000 \ldots$ & 8 & 4 & 25 \\
$\$ 10,000-\$ 24,999 \ldots$. & 25 & 7 & 28 \\
$\$ 25,000-\$ 49,999 \ldots$. & 53 & 18 & 39 \\
$\$ 50,000-\$ 99,999 \ldots$. & 74 & 28 & 49 \\
$\$ 100,000$ or more $\ldots .$. & 91 & 57 & 63 \\
All families ......... & $\mathbf{4 9}$ & $\mathbf{1 9}$ & $\mathbf{5 4}$ \\
\hline
\end{tabular}

1. Retirement accounts include individual retirement accounts and employersponsored defined contribution pension plans.

2. Includes both direct and indirect stock holdings and is based on families that have some stock holdings.

Source. Survey of Consumer Finances. 
to almost half in $1998 . .^{15}$ Across all but the highest income levels, households are more likely to own stock indirectly and in retirement accounts than directly outside of retirement accounts (table 3 ). In 1998, only 19 percent of households owned stock directly outside of a retirement account whereas 30 percent owned stock indirectly (often through a mutual fund) or in a retirement account. For many households, retirement accounts are an important point of access to the equity market; 49 percent of all households owned some type of retirement account in 1998, up from 35 percent in 1989. ${ }^{16}$

\section{MUTUAL FUNDS AND RETIREMENT ASSETS}

Over the past two decades, the growth of individual retirement accounts (IRAs) and a shift from defined benefit to defined contribution pension plans have given households considerably more control over the portfolio allocation of their retirement assets. At the same time, mutual funds have become an increasingly important component of households' retirement accounts.

IRAs generally feature tax-deductible annual contributions and tax-free accrual of investment earnings. Once the account holder reaches age 591/2, assets withdrawn from the IRA are taxed as ordinary income; in addition, a tax penalty is usually imposed on assets withdrawn before that age. Traditional IRAs were established in 1974, but because they were available only to workers not covered by an employer-provided pension, they were not common. ${ }^{17}$ In 1981, eligibility was extended to all workers and the annual tax-deductible contribution limits were increased. IRAs subsequently became quite popular. ${ }^{18}$ The Tax Reform Act of 1986 retained universal eligibility and the tax-free accrual of invest-

15. See Kennickell and others, "Recent Changes in U.S. Family Finances," table 6, p. 15. A 1999 survey by the Investment Company Institute and the Securities Industry Association (Equity Ownership in America, ICI and SIA, 1999, p. 5) found that 48 percent of households owned stock, a proportion very close to that found in the 1998 Survey of Consumer Finances.

16. Data for 1998 are from Kennickell and others, "Recent Changes in U.S. Family Finances," table 5, pp. 10-11; 1989 data are from Arthur Kennickell and Martha Starr-McCluer, "Changes in U.S. Family Finances from 1989 to 1992: Evidence from the Survey of Consumer Finances," Federal Reserve Bulletin, vol. 80 (October 1994), table 5, pp. 868-69.

17. For more discussion of the development and details of IRAs, see Eric M. Engen, William Gale, and John Karl Scholz, "Do Saving Incentives Work?" Brookings Papers on Economic Activity, vol. 1 (1994) pp. 85-180, and Investment Company Institute, "IRA Ownership in 2000," Fundamentals, vol. 9 (October 2000).

18. By 1986, annual contributions to IRAs had risen to more than $\$ 35$ billion.
4. Distribution of IRA assets by type of institution, selected years, 1985-99

Percent

\begin{tabular}{c|r|r|r|r}
\hline Type of institution & 1985 & 1990 & 1995 & 1999 \\
\hline Mutual funds ............... & 17 & 22 & 37 & 49 \\
Brokerage accounts ......... & 14 & 28 & 35 & 32 \\
Life insurance companies .... & 9 & 8 & 7 & 9 \\
Bank and thrift deposits ...... & 60 & 42 & 20 & 10 \\
\hline
\end{tabular}

Note. Distributions may not sum to 100 percent because of rounding. Source. Investment Company Institute.

ment earnings for IRAs but restricted the tax deductibility of contributions for higher-income households that were covered by an employer-provided pension plan; subsequently, annual contributions to traditional IRAs dropped substantially. ${ }^{19}$ Legislation enacted in 1997 introduced Roth IRAs, which permit non-taxdeductible contributions. All distributions from these accounts are untaxed, assuming that certain early withdrawal restrictions are not violated. Roth IRAs have renewed investor interest in IRAs. Several types of employer-sponsored IRAs are available to selfemployed individuals and employees of small businesses; they are similar to tax-deductible traditional IRAs but typically have higher contribution limits. ${ }^{20}$

IRA ownership has grown considerably over the two decades since the accounts became universally available. In June 2000, 41 percent of all U.S. households owned at least one type of IRA. ${ }^{21}$ Of those households that owned an IRA, 78 percent held a traditional IRA, 24 percent a Roth IRA, and 17 percent an employer-sponsored IRA. ${ }^{22}$ As ownership was growing, mutual funds were becoming an increasingly important institution for the management of IRA assets, holding almost half of those assets in 1999 (table 4).

Households have also gained greater control over the investment of their pension assets. Employersponsored pension plans have increasingly shifted away from traditional defined benefit plans, which typically do not allow employees to decide how their

19. Annual contributions to traditional IRAs, including both tax deductible and non-deductible contributions, averaged less than \$11 billion from 1990 through 1998.

20. Simplified employee pension IRAs (SEP IRAs) were created in 1978. SAR-SEP IRAs are a special type of SEP IRA with a salary reduction feature; the formation of new SAR-SEPs has been prohibited since 1996 but established SAR-SEPs can still be used. SIMPLE IRAs were introduced in 1996 for small business employers. Keogh plans, which were established in 1962, are defined contribution pension plans similar to SEP IRAs that can be set up by sole proprietors and partnerships.

21. Investment Company Institute, "IRA Ownership in 2000," p. 1.

22. These numbers sum to more than 100 percent because some households own more than one type of IRA. 
5. Distribution of private pension plan assets by type of plan, selected years, 1975-99

Percent

\begin{tabular}{|c|c|c|c|c|c|c|}
\hline Type of plan & 1975 & 1980 & 1985 & 1990 & 1995 & 1999 \\
\hline $\begin{array}{l}\text { Defined benefit ..... } \\
\text { Defined contribution }\end{array}$ & $\begin{array}{l}72 \\
28\end{array}$ & $\begin{array}{l}71 \\
29\end{array}$ & $\begin{array}{l}66 \\
34\end{array}$ & $\begin{array}{l}55 \\
45\end{array}$ & $\begin{array}{l}50 \\
50\end{array}$ & $\begin{array}{l}45 \\
55\end{array}$ \\
\hline
\end{tabular}

Source. Flow of funds accounts.

plan assets are invested, toward defined contribution plans, which usually give employees considerable discretion in the investment of those assets. In 1980, defined benefit plans held more than 70 percent of the assets in all private pension funds (table 5). As defined contribution plans became more popular, their assets grew, so that they now hold 55 percent of all private pension assets. This shift in private pension assets has been important to mutual funds because defined contribution plans are much more likely to use mutual funds to manage their assets (table 6).

The percentage of working households (that is, households with at least one employed adult) that are covered by a pension and have a defined contribution plan has also risen (table 7). In 1989, 40 percent of working households with a pension were covered by only a defined benefit plan, and another 31 percent were covered by both a defined benefit and a defined contribution plan; only 30 percent were covered solely by a defined contribution plan. By 1998, 57 percent of working households with pension coverage had only a defined contribution plan, and another 25 percent were covered by both types of plans; only 18 percent were covered solely by a defined benefit plan. As defined contribution plans became more common, the percentage that were

6. Distribution of financial assets in private defined benefit and defined contribution pension funds by type of asset, selected years 1985-99

Percent

\begin{tabular}{|c|c|c|c|c|}
\hline Type of asset & 1985 & 1990 & 1995 & 1999 \\
\hline \multicolumn{5}{|l|}{ Defined benefit funds } \\
\hline Cash $^{1} \ldots \ldots \ldots \ldots . . . . .$. & 7 & 7 & 6 & 5 \\
\hline Bonds $\ldots \ldots \ldots \ldots$. & 32 & 39 & 32 & 26 \\
\hline Equities . & 42 & 38 & 48 & 54 \\
\hline Mutual funds $\ldots . \ldots$. & 1 & 1 & 4 & 6 \\
\hline Insurance contracts ${ }^{2}$. & 10 & 8 & 5 & 5 \\
\hline Other financial assets & 8 & 7 & 5 & 4 \\
\hline \multicolumn{5}{|c|}{ Defined contribution funds } \\
\hline $\operatorname{Cash}^{1} \ldots \ldots \ldots \ldots \ldots$ & 10 & 10 & 3 & 1 \\
\hline Bonds. & 19 & 17 & 12 & 7 \\
\hline Equities . & 39 & 36 & 40 & 44 \\
\hline Mutual funds $\ldots \ldots \ldots$ & 3 & 7 & 21 & 30 \\
\hline Insurance contracts ${ }^{2}$. & 12 & 19 & 17 & 13 \\
\hline Other financial assets & 16 & 12 & 7 & 5 \\
\hline
\end{tabular}

Note. Distributions may not sum to 100 percent because of rounding.

1. Includes currency, insured deposits, and repurchase agreements; does not include money market mutual funds, which are included with mutual funds. 2. Includes mutual funds held in variable annuities.

Source. Flow of funds accounts. 401(k) plans rose, reaching 78 percent in 1998 , making them the most popular type of plan.

Like IRAs, 401(k) plans feature tax-deductible contributions, tax-free accrual of investment returns, annual contribution limits, and restrictions on withdrawals. ${ }^{23}$ Employees who separate from a firm sponsoring a plan before retirement age must pay income taxes on the withdrawn funds at ordinary rates; in addition, they also face a tax penalty unless they roll the funds over into an IRA or another 401(k) account. ${ }^{24}$ Unlike IRAs, 401(k) plans are available only to employees of firms that choose to sponsor the plans. Employers may also make tax-deductible contributions to employees' accounts, and total contribution limits are generally higher for 401(k) plans than for IRAs. Also, employers select the investment options available in $401(\mathrm{k})$ plans; as a result, the number of options is typically more limited than in an IRA. In 1998, the typical 401(k) plan offered six to nine investment options. ${ }^{25}$ These options usually included equity, bond, and money market funds. More than 70 percent of the plans offered an equity fund option, making it the most popular option offered by sponsoring employers. ${ }^{26}$

23. These plans, which were established in 1978, are named after section 401(k) of the Internal Revenue Code, which authorizes their use. Other types of defined contribution plans include 403(b) and 457 plans, which are available to employees of nonprofit institutions and state and local governments respectively; and thrift plans, which are available to employees of the federal government. These other types of plans are similar to 401(k) plans in many respects. See Engen and others, “Do Saving Incentives Work?" for more discussion of 401(k) plans.

24. As a consequence, rollovers from 401(k) accounts and other types of defined contribution pension plan accounts have been an important source of funds to IRAs in recent years. Forty-six percent of the owners of traditional IRAs and 13 percent of Roth IRA owners have in their IRAs assets that were converted from an employersponsored pension plan. See Investment Company Institute, "IRA Ownership in 2000," pp. 2, 4.

25. The Investment Company Institute reported that the median number of investment options in 401(k) plans was six, whereas Hewitt Associates reported that the median number was nine. See Investment Company Institute, 401(k) Plan Participants: Characteristics, Contributions, and Account Activity (Spring 2000), p. 20; and Hewitt Associates, Trends and Experience in 401(k) Plans (1999), p. 27.

26. See Investment Company Institute, 401(k) Plan Participants, p. 22. This survey did not make a distinction between mutual funds and other pooled investment vehicles, such as trusts and separate accounts. 
7. Pension coverage for working households, by type of plan, selected years, 1989-98 Percent

\begin{tabular}{|c|c|c|c|c|c|c|}
\hline \multirow{2}{*}{ Year } & \multirow{2}{*}{$\begin{array}{l}\text { Households } \\
\text { covered }\end{array}$} & \multicolumn{3}{|c|}{$\begin{array}{l}\text { Distribution of plans } \\
\text { by type }\end{array}$} & \multicolumn{2}{|c|}{$\begin{array}{c}\text { Distribution of defined contribution plans } \\
\text { by type }\end{array}$} \\
\hline & & $\begin{array}{l}\text { Defined benefit } \\
\text { only }\end{array}$ & $\begin{array}{l}\text { Defined contribution } \\
\text { only }\end{array}$ & $\begin{array}{l}\text { Both defined benefit } \\
\text { and defined } \\
\text { contribution }\end{array}$ & $401(\mathrm{k})$ & Other \\
\hline 1989 & 55 & 40 & 30 & 31 & 55 & 45 \\
\hline 1992 & 55 & 35 & 37 & 27 & 48 & 52 \\
\hline 1995 & 54 & 23 & 52 & 24 & 65 & 35 \\
\hline 1998 & 55 & 18 & 57 & 25 & 78 & 22 \\
\hline
\end{tabular}

NoTE. Distributions may not sum to 100 percent because of rounding. Working households are those with at least one employed adult.

Total retirement assets increased threefold over the past decade, to almost $\$ 13$ trillion in 1999 (table 8). ${ }^{27}$ Mutual funds have played an increasingly important role in this growth, accounting for almost one-fifth of total retirement assets in 1999. Moreover, retirement assets held within mutual funds have risen significantly relative to total mutual fund assets, accounting for 35 percent of total fund assets in 1999.

Households have chosen to allocate the bulk of the retirement assets they hold in mutual funds to equities, thus bolstering the total share of mutual fund assets allocated to equity funds (table 9). In 1999, 73 percent of mutual fund IRA assets and 81 percent of mutual fund defined contribution pension plan assets were invested in equity funds. ${ }^{28}$ Retirement account assets in mutual funds are much more likely than non-retirement-account assets in mutual funds to be devoted to equity investments.

The growing role of retirement assets in households' equity mutual fund holdings might be expected to affect mutual fund shareholders' investment behavior. One hypothesis is that households take a longerterm perspective with the funds they have invested in

27. Total retirement assets consist of assets in IRAs, private employer-sponsored pension plans (both defined contribution and defined benefit plans), federal, state, and local government employee retirement funds, and annuity reserves at life insurance companies.

28. About two-thirds of defined contribution pension plan assets invested in mutual funds come from 401(k) plans; the remainder come from 403(b), 457, and other defined contribution pension plans. retirement accounts. In this view, these households would be less likely to trade frequently and, in particular, less likely to redeem their equity fund shares in response to temporary stock-price declines. An alternative hypothesis is that households switch more frequently between equity funds and money market or bond funds because the earnings in retirement accounts, including capital gains, are not taxed. In this view, households with equity funds in retirement accounts would be more likely to trade frequently and, in particular, more likely to redeem their equity fund shares in response to stock-price declines.

Testing these hypotheses and determining the overall effect of equity mutual fund investing on stock prices is an empirical issue. In the next section we analyze the evidence concerning the relationship between mutual fund investors' behavior and equity market developments.

\section{MUTUAL FUNDS AND FINANCIAL MARKETS}

Mutual funds hold about 20 percent of the publicly traded stocks of U.S. corporations. This proportion not only is much greater than it was a decade ago, but it also is larger than the proportion of the bond market held by mutual funds (chart 9).

The growing importance of mutual funds in the U.S. equity market increases the possibility that

8. Retirement assets, by type, selected years, 1990-99

\begin{tabular}{|c|c|c|c|c|c|c|}
\hline \multirow[b]{2}{*}{ Year } & \multicolumn{3}{|c|}{$\begin{array}{l}\text { Total retirement assets } \\
\text { (trillions of dollars) }\end{array}$} & \multicolumn{3}{|c|}{$\begin{array}{l}\text { Mutual fund retirement assets } \\
\text { (billions of dollars) }\end{array}$} \\
\hline & $\begin{array}{l}\text { Individual } \\
\text { retirement } \\
\text { accounts }\end{array}$ & $\begin{array}{l}\text { All employer- } \\
\text { sponsored } \\
\text { pension plans }\end{array}$ & $\begin{array}{l}\text { Memo: } \\
\text { Mutual fund } \\
\text { retirement assets } \\
\text { as a share of total } \\
\text { retirement assets } \\
\quad \text { (percent) }\end{array}$ & $\begin{array}{l}\text { Individual } \\
\text { retirement } \\
\text { accounts }\end{array}$ & $\begin{array}{c}\text { Employer- } \\
\text { sponsored } \\
\text { defined contribution } \\
\text { pension plans }\end{array}$ & $\begin{array}{c}\text { Memo: } \\
\text { Mutual fund } \\
\text { retirement assets } \\
\text { as a share of total } \\
\text { mutual fund assets } \\
\text { (percent) }\end{array}$ \\
\hline 1990 & .6 & 3.4 & 5 & 141 & 67 & 19 \\
\hline 1995 & 1.3 & 5.7 & 13 & 479 & 439 & 33 \\
\hline 1999 & 2.5 & 10.2 & 19 & 1,222 & 1,204 & 35 \\
\hline
\end{tabular}

Source. Investment Company Institute. 
9. Distribution of mutual fund assets within different types of accounts, by type of fund, 1999 Percent

\begin{tabular}{|c|c|c|c|c|c|}
\hline Type of mutual fund account & Domestic equity fund & Foreign equity fund & Hybrid fund & Bond fund & Money market fund \\
\hline IRA $\ldots \ldots \ldots, \ldots, \ldots$ & 63 & 10 & 8 & 8 & 11 \\
\hline Defined contribution pension plan & 73 & 8 & 8 & 5 & 6 \\
\hline All other mutual fund accounts .... & 41 & 8 & 4 & 15 & 32 \\
\hline
\end{tabular}

Source. Investment Company Institute.

households' decisions to invest new cash in, or request redemptions from, equity mutual funds significantly affect equity prices. This possibility can be evaluated by looking at the relationship between domestic equity fund flows and equity prices. Net new flows into domestic equity funds as a percentage of the value of the U.S. stock market have tended to increase over the past fifteen years (chart 10). ${ }^{29}$ The monthly percent change in the Wilshire 5000 index of stock prices over the same period shows that while equity fund flows were becoming more stable, equity prices were becoming more volatile (chart 11). ${ }^{30} \mathrm{~A}$ related development is that the response of mutual fund investors to large market declines-specifically, the equity price declines in October 1987, August 1990, and August 1998-has become progressively smaller.

In October 1987, when the Wilshire index fell more than 20 percent (the worst monthly perfor-

29. Average monthly domestic equity fund inflows were 0.02 percent of the market's value over the period $1985-89$, rose to 0.10 percent over 1990-94, and rose further, to 0.14 percent, over 1995-99.

30. The coefficient of variation for domestic equity fund inflows (defined as the standard deviation of fund flows divided by the mean of fund flows) was 2.9 over the period 1985-89, dropped to 0.6 over 1990-94, and fell further, to 0.4, over 1995-99.

9. Percentage of total outstanding securities held by mutual funds, 1984:Q1-2000:Q2

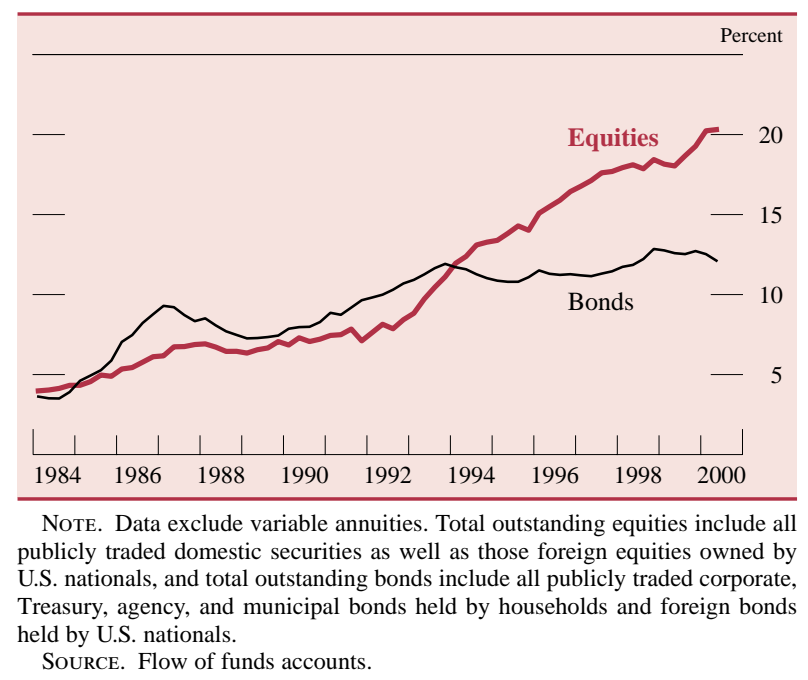

mance for the stock market since World War II), domestic equity funds experienced net outflows of more than $\$ 6$ billion. This outflow amounted to 0.2 percent of the total value of the stock market, or just under 3 percent of domestic equity fund assets; this was the largest monthly outflow as a percentage of fund assets to date. Indeed, domestic equity funds experienced outflows in fourteen of the sixteen months following the October crash, outflows that summed to a net total of more than $\$ 18$ billion. All told, mutual fund shareholders withdrew more than 11 percent of domestic equity fund assets in the aftermath of the October 1987 episode. ${ }^{31}$

The next large decline in stock prices occurred in August 1990, when the Wilshire index fell about 10 percent in the wake of concerns about the Gulf War in Kuwait and Iraq. In that month, mutual fund shareholders withdrew about $\$ 2 \frac{1}{2}$ billion from domestic equity funds, which amounted to less than 0.1 percent of the value of the stock market, or about 1 percent of domestic equity fund assets. Outflows from August through September 1990 were only $\$ 3$ billion, or a little more than 1 percent of fund assets. Although the Wilshire index fell half as far in August 1990 as it had in October 1987, fund withdrawals during the 1990 episode were less than half those during the 1987 episode.

Domestic equity funds did not experience a net monthly outflow again until August 1998, when the Wilshire index declined 15 percent in the midst of the Asian financial market crisis and Russian bond defaults. Shareholders in domestic equity funds requested net redemptions of about $\$ 61 / 2$ billion in that month, an amount equal to about 0.3 percent of total domestic equity fund assets. Domestic equity fund inflows resumed the following month. Thus, redemptions in August 1998 were substantially

31. John Rea and Richard Marcis ("Mutual Fund Shareholder Activity during U.S. Stock Market Cycles," Investment Company Institute Perspective, vol. 2, March 1996, pp. 1-16) show that during the bear markets in the 1970 s, equity fund shareholders were sensitive to prolonged share price declines. Equity funds had outflows in almost every month between 1971 and 1982 as the stock market waded through three periods of price contraction, including the long bear market over 1973 and 1974, when the S\&P 500 index declined 48 percent. 
10. Net new cash flows to domestic equity mutual funds as a percentage of the value of the U.S. stock market, January 1984-August 2000

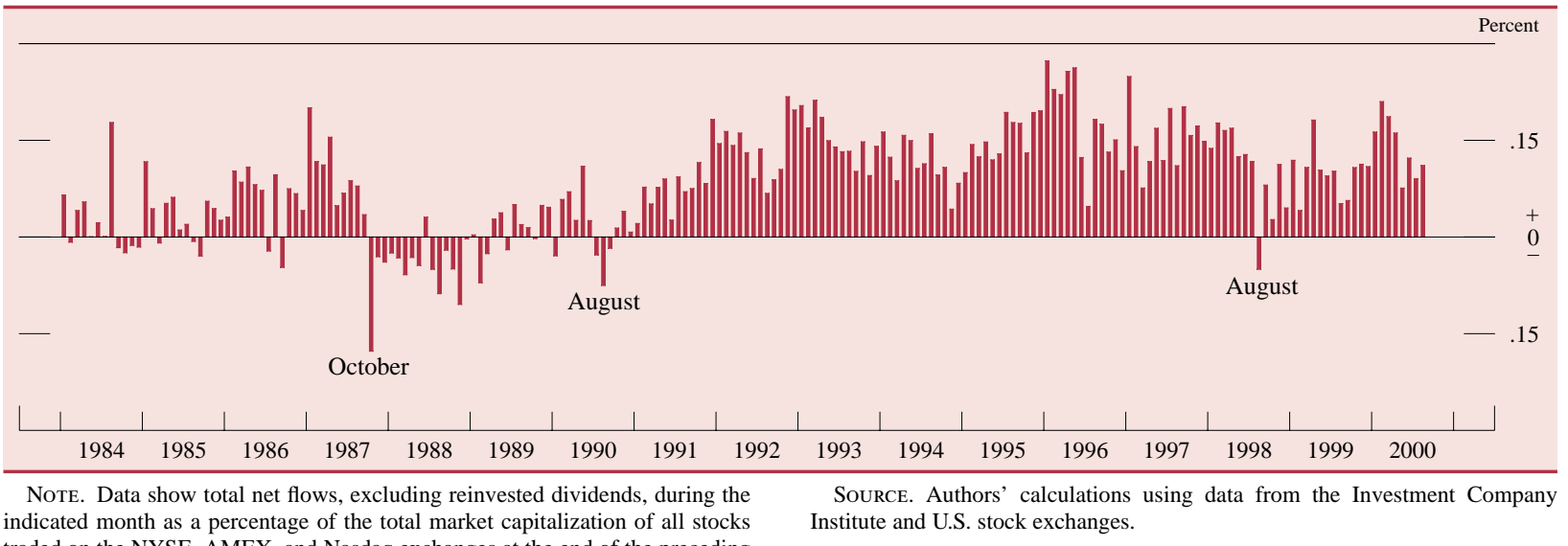
indicated month as a percentage of the total market capitalization of all stocks traded on the NYSE, AMEX, and Nasdaq exchanges at the end of the preceding month.

\section{Change in the Wilshire 5000 index, January 1984-August 2000}

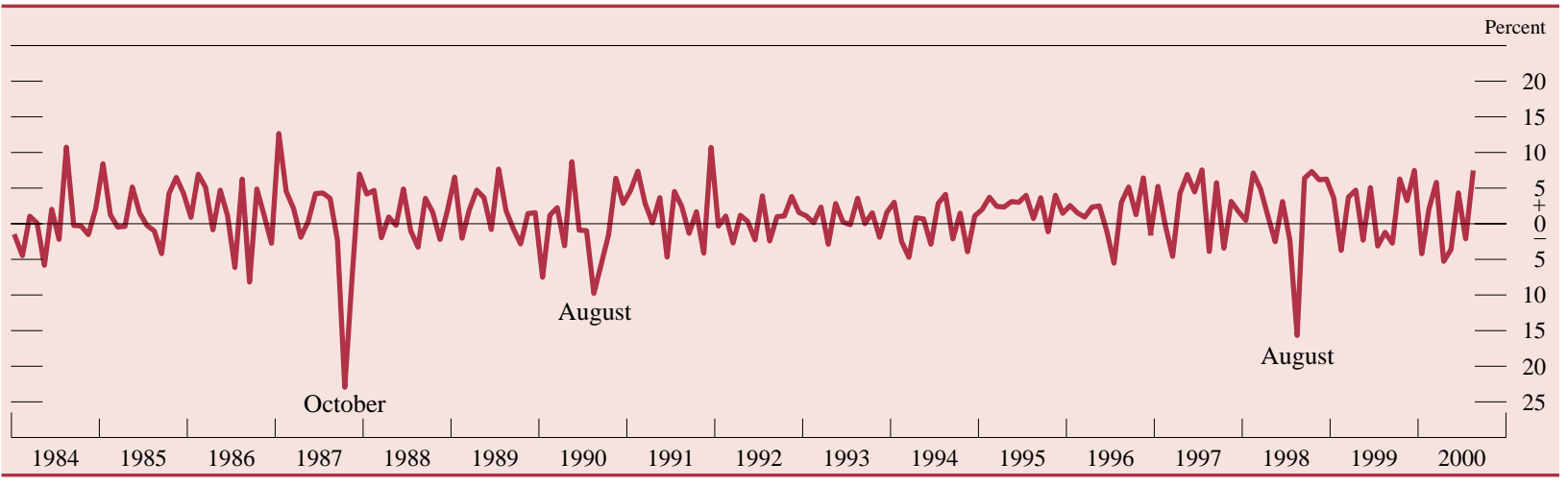

NoTE. Data show the percent change in the index from the last business day of the preceding month to the last business day of the month shown.

smaller, as a percentage of assets, than those in August 1990, even though the stock price decline in 1998 was greater.

Although investors have withdrawn money from domestic equity funds during severe market declines, mutual fund managers have not necessarily had to sell stocks immediately to cover redemptions. In addition to holding stocks, equity funds also hold safe, liquid money market assets, usually referred to as "cash." The proportion of a mutual fund's total assets held in cash is known as the cash ratio. To the extent that net outflows can be met by cash on hand, they need not translate into forced sales of equities by fund managers. The asset-weighted mean cash ratio for all domestic equity funds has generally been trending down and recently stood a little above 4 percent (chart 12). Despite the decline, funds have had, on average, more than enough cash on hand to cover monthly redemptions throughout the past fifteen years. Moreover, the frequency and magnitude of net redemptions from equity funds, as a percentage of assets, have diminished over time. ${ }^{32}$

A fund's cash holdings are not its only means of meeting a short-term episode of redemptions without selling some of its equity portfolio. Many families of mutual funds now have committed lines of credit to help meet unexpectedly large temporary outflows. ${ }^{33}$ Also, some large fund families have been allowed by the Securities and Exchange Commission to borrow between funds. Thus, an outflow from an equity fund, for example, could be covered by borrowing at a fair

32. On average, net redemption rates have been far below equity funds' cash ratios on a monthly basis; however, some individual funds may have needed to sell some of their equity portfolio to meet redemption requests.

33. Mutual fund credit lines are typically used for short-term adjustments. It is possible for funds to use leverage as part of their long-term portfolio management, but they must have at least \$3 in assets for each $\$ 1$ they borrow. In practice, very few mutual funds use long-term leverage. 
12. Domestic equity fund cash holdings and outflows as a percentage of fund assets, January 1984-August 2000

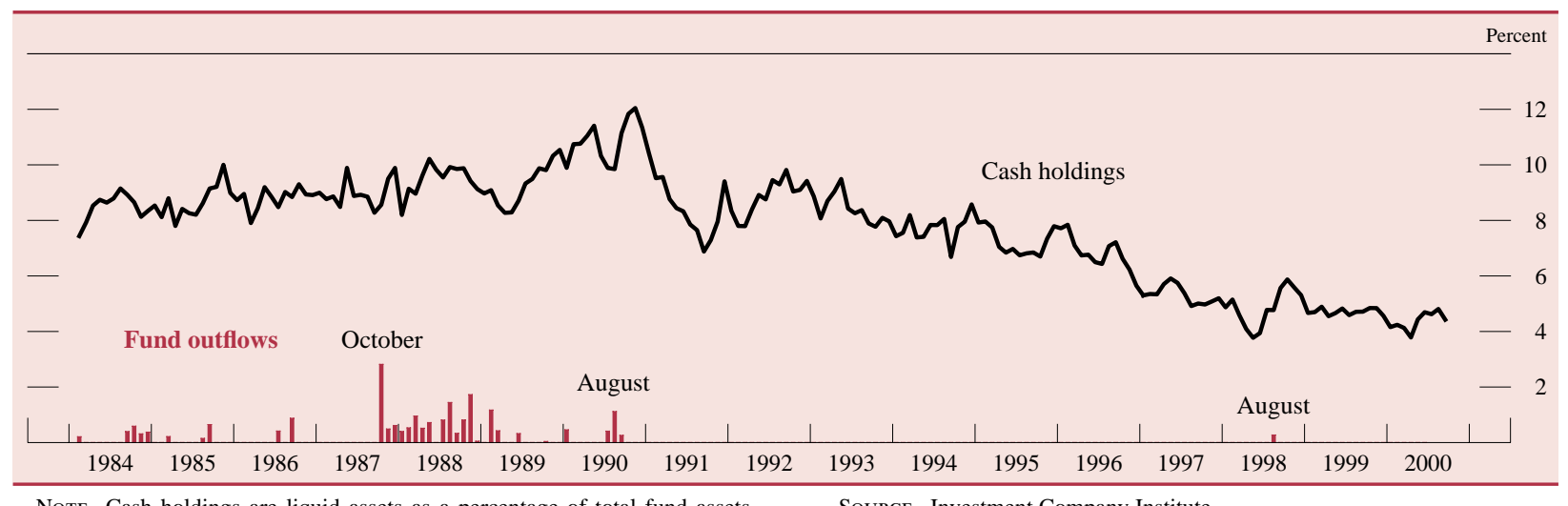

Note. Cash holdings are liquid assets as a percentage of total fund assets. Fund outflows are net for the month; months with net inflows are not shown.

market rate from another fund in the family that is receiving inflows-say, a bond or money fund.

Credit lines and fund-family borrowing agreements can serve as additional buffers that, along with those traditionally provided by funds' liquid assets, help equity fund managers avoid having to sell equities in a slumping market. However, temporary periods of sharp equity price declines may not be the only time equity fund shareholders' behavior could have affected equity prices. Equity fund flows may have had more subtle effects on equity priceseffects that may have been small and that may have appeared only with a delay. Evidence of these effects can be sought by calculating correlation coefficients that measure the strength and direction of the co-movement of equity mutual fund flows and changes in equity prices over time. Analysis of these correlation coefficients can give some indication of whether equity mutual fund flows cause changes in equity market prices, or the other way around, or neither. (A more detailed statistical treatment of this issue is given in the appendix.)

As would be expected, given that cash has flowed out of domestic equity funds in months with steep stock market declines, fund flows and stock price changes have a positive contemporaneous correlation, averaging about 0.6 for the period since 1984 (chart 13, upper panel). This contemporaneous correlation is statistically significant, although it has declined over time, from 0.7 in the mid-1980s to below 0.25 more recently. Thus, as an increasing proportion of equity mutual funds were being held in retirement accounts, flows to equity mutual funds were becoming less sensitive to market performance.

This positive contemporaneous correlation says little about the direction of causality (if any) between domestic equity fund flows and equity price changes. Three causal relationships are possible: price changes could cause flows, flows could cause price changes, or both flows and price changes could react to new information that affects the market's perceived value of stocks. Exploring the alternative hypotheses associated with these relationships requires an examination of the effect of lagged price changes on current flows and of lagged flows on current price changes.

The feedback trading hypothesis provides one possible explanation for a positive correlation between domestic equity fund flows and equity price changes. Mutual fund investors may be feedback traders, that is, they may follow the stock market, so that an increase in equity prices one month would be followed by a positive flow the next month. However, the average correlation between current flows and price changes lagged one month has been essentially zero since 1984 (chart 13, middle panel). Thus, at least when the analysis is based on monthly data, the feedback trading hypothesis is not supported.

A second hypothesis-the price pressure hypothesis-holds that the contemporaneous correlation arises because flows exert upward pressure on stock prices for reasons other than changes in available information that affect the market's valuation of stocks. After such an increase, equity prices would decline as they return to a level more consistent with the general market perception of the appropriate level of stock valuation. This hypothesis can be tested by calculating the correlation between current price changes and lagged flows (that is, the effect of flows one month on price changes the next). Consistent with this hypothesis, the correlation coefficient is negative; the correlation is weak, however, averaging only about -0.2 (chart 13 , lower panel), and is not statistically significant.

Finally, the information hypothesis maintains that equity mutual fund investors, like other investors in the equity market, merely trade on the basis of new 
information that the market uses to value equities. If this hypothesis is correct, then stock price declines should not follow equity fund inflows. The finding that equity fund flows and stock price changes are significantly correlated only contemporaneously is consistent with this hypothesis. Econometric analysis (reported in the appendix) generally confirms the evidence suggested by the correlation coefficients. Overall, there is little evidence that mutual fund investors have been a destabilizing force in equity markets over the past fifteen years.

13. Correlation between domestic equity mutual fund flows and stock market price changes, January 1985-August 2000

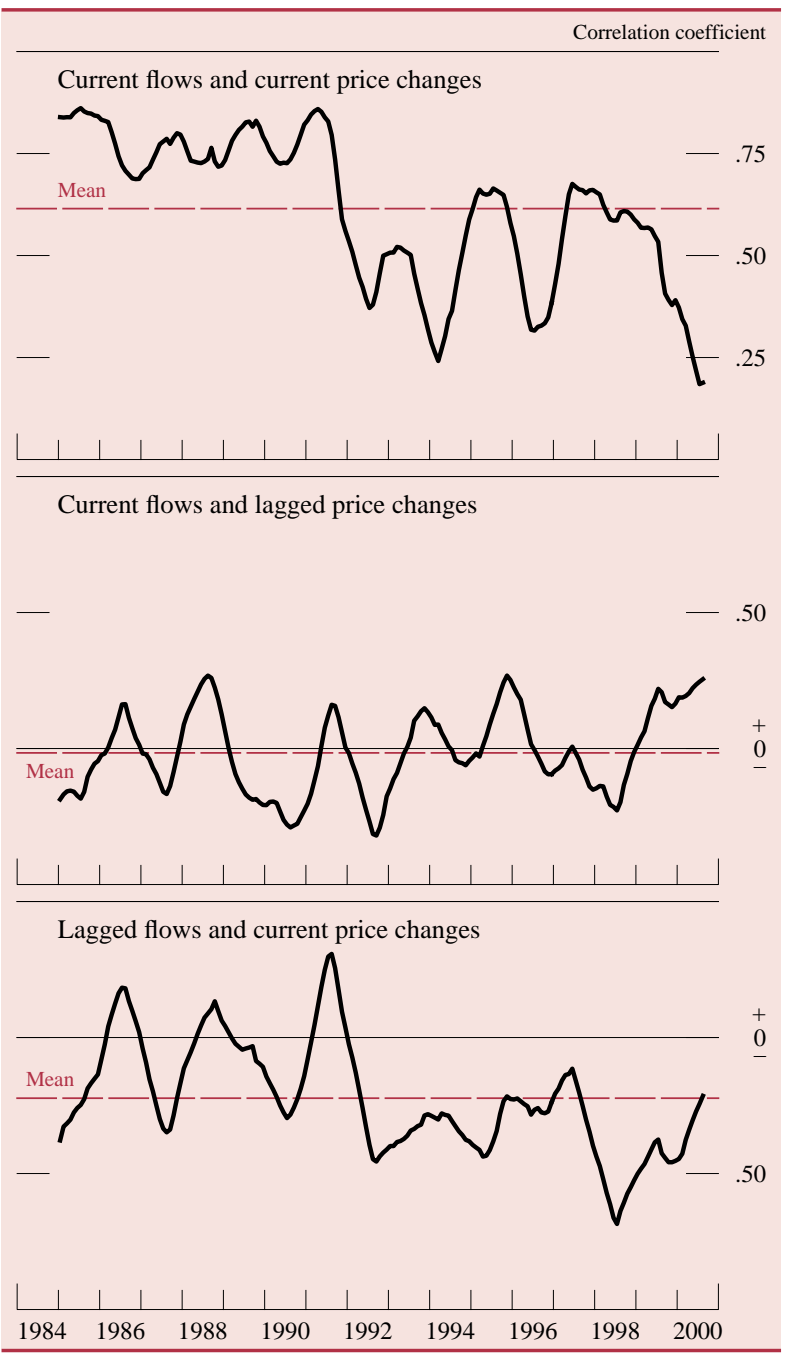

Note. Data show the twelve-month moving average of the correlation between (1) net new cash flows to domestic equity funds as a percentage of the value of the U.S. stock market and (2) the percentage change in the Wilshire 5000 index from the end of the preceding month to the end of the indicated month. Correlation coefficients are calculated using data for the twelve months preceding the indicated month. Monthly values for stock market capitalization are smoothed to conform to the market's long-run growth rate.

Source. Authors' calculations.

\section{CONCLUSION}

Mutual funds have grown rapidly over the past decade, both in absolute terms and as a percentage of household assets, in large part because of the growth of retirement saving accounts. In defined contribution pension plans and individual retirement accounts, households directly control the allocation of their retirement assets and often use equity mutual funds as the primary vehicle for investing them.

There is little evidence that over the past decade or so mutual fund investors have traded in a manner that has significantly influenced stock prices independently of the rest of the market, or that mutual fund investors have been entering and exiting equity funds merely on the basis of past price changes in the stock market. Equity fund investors appear to have behaved like other investors in the equity market and simply traded on the basis of new information that the market uses to value equities. Thus, there is little indication that mutual fund investors have in recent history been a destabilizing force in the equity market even as mutual funds were becoming larger players in the market. Further, the evidence suggests that fund shareholders who held retirement accounts were generally focused on investing for the long term rather than using these tax-sheltered accounts for active trading, because even as retirement assets were becoming an increasingly larger share of equity fund assets, fund flows were becoming less sensitive to stock price changes.

\section{APPENDIX: ECONOMETRIC ANALYSIS OF EQUITY MUTUAL FUND FLOWS AND STOCK MARKET PRICE CHANGES}

Correlation coefficients and other simple statistics can provide only limited insight into the behavior of mutual fund investors. In this appendix, we investigate the relationship between equity mutual fund flows and equity market price changes using regression analysis. We find no compelling evidence that fund flows cause stock price changes or that stock market price changes cause fund flows.

As noted in the main text, more cash tends to flow into domestic equity mutual funds in months when the stock market does well than in months when it does poorly. The most likely explanations for this contemporaneous correlation are the price pressure hypothesis and the information hypothesis.

A related issue is whether or not mutual fund investors are following a feedback strategy, so that equity fund inflows react to past values of stock 
market price changes. Several fund-level studies have found that mutual fund investors transfer money into individual mutual funds that are doing well and out of individual funds that are doing poorly. ${ }^{34}$ This finding is not evidence, however, that in the aggregate, mutual fund investors choose to invest in equity funds as a whole (as opposed to, say, money market funds) on the basis of previous months' equity market price changes. If mutual fund investors are indeed feedback traders, we would be less likely to believe the information hypothesis, which requires that mutual fund investors react mainly to new information about stocks.

We find evidence that strongly favors the information hypothesis and are able to reject the price pressure hypothesis in most cases. We can consistently reject the feedback trading hypothesis. On balance, our results indicate that flows to equity mutual funds do not generally push stock prices above the level determined by other market participants. ${ }^{35}$

\section{Econometric Modeling of Flows}

Our analysis concentrates on net new cash flows to domestic equity mutual funds and percent changes in domestic equity market prices. We use data on the monthly aggregate flow of new cash, excluding reinvested dividends, to all domestic equity funds for January 1984 through August 2000 collected by the Investment Company Institute. Our measure of equity price changes is the percent change in the Wilshire 5000 index of stocks from the last business day of one month to the last business day of the next month.

To test our hypotheses, we construct the following normalized fund flow variable:

34. Richard A. Ippolito, "Consumer Reaction to Measures of Poor Quality: Evidence from the Mutual Fund Industry," Journal of Law and Economics, vol. 35 (April 1992), pp. 45-70; Judith Chevalier and Glenn Ellison, "Risk Taking by Mutual Funds as a Response to Incentives," Journal of Political Economy, vol. 105 (December 1997), pp. 1167-200; and Roger M. Edelen, "Investor Flows and the Assessed Performance of Open-End Mutual Funds," Journal of Financial Economics, vol. 53 (September 1999), pp. 439-66.

35. Our analysis follows that by Vincent A. Warther, "Aggregate Mutual Fund Flows and Security Returns," Journal of Financial Economics, vol. 39 (October 1995), pp. 209-35, and "Has the Rise of Mutual Funds Increased Market Instability?" in Robert Litan and A. Santomero, eds., Brookings-Wharton Papers on Financial Services (Brookings Press, 1998), pp. 239-80. See also Mark Grinblatt, Sheridan Titman, and Russ Wermers, "Momentum Investment Strategies, Portfolio Performance, and Herding: A Study of Mutual Fund Behavior," American Economic Review, vol. 85 (December 1995), pp. 1088-105; and L. Franklin Fant, "Investment Behavior of Mutual Fund Shareholders: The Evidence from Aggregate Fund Flows," Journal of Financial Markets, vol. 2 (1999), pp. 391-402.

$$
f(t)=100 \frac{F(t)}{A_{0}(1+g)^{t-1}}, t=1, \ldots, 200
$$

Here, $t=1$ refers to the first month in the sample period (January 1984) and $t=200$ refers to the last month in the period (August 2000). $F(t)$ is the dollar value of net new cash flows into domestic equity funds, $A_{0}$ is the dollar value of the total U.S. stock market capitalization (NYSE + AMEX + Nasdaq) at the beginning of the sample period, and $g$ equals 0.01134 (the average monthly rate of growth of the stock market over the period). Thus $f(t)$ can be thought of as fund flows as a percentage of smoothed stock market capitalization. Deflating flows $F(t)$ by the actual beginning-of-period stock market capitalization would introduce a direct effect of stock market price changes on flows, as the stock market grows and shrinks with price changes. This direct effect would bias downward any estimates of the effect of lagged price changes on current flows because flows would appear smaller (as a percentage of the stock market) precisely when the stock market does well. Therefore, to avoid this bias we normalize fund flows by the smoothed, not the actual, stock market capitalization.

To test the competing price pressure and information hypotheses, one might run the following regressions:

(1a) $f(t)=k_{b}+b_{0} R(t)+b_{1} R(t-1)+\ldots+b_{6} R(t-6)$

(1b) $R(t)=k_{c}+c_{0} f(t)+c_{1} f(t-1)+\ldots+c_{6} f(t-6)$.

Here, $f(t)$ is the normalized flow variable explained above, $R(t)$ is the monthly percent change in the Wilshire 5000 index of stocks, and $k_{b}$ and $k_{c}$ are the constant terms in the regression. The regression coefficient estimates for equations $1 \mathrm{a}$ and $1 \mathrm{~b}$ are shown in table A.1. They appear to support the price pressure hypothesis, as current price changes are negatively correlated with lagged flows. They also seem to support the feedback trading hypothesis, because current flows are positively correlated with lagged price changes.

These results are almost completely driven by misspecification. Suppose that there is a slow-moving trend in mutual fund flows (as is strongly suggested by chart 10), so that flows in a given month are made up of this trend and the effect of that month's information $I(t)$. Assume that the trend component of flows can be captured by a simple autoregressive process with six months of lags. Under the information hypothesis, price changes and flows (correcting 


\section{A.1. Regressions of flows on price changes} and price changes on flows

\begin{tabular}{|c|c|}
\hline Independent variable & Coefficient \\
\hline & Flows on price changes \\
\hline Constant ..... & $.04154 * * *$ \\
\hline Price change $t \ldots$. & $.00750 * * *$ \\
\hline Price change $t-1$ & $.00214 * *$ \\
\hline Price change $t-2$ & $.00277 * * *$ \\
\hline Price change $t-3$ & $.00290 * * *$ \\
\hline Price change $t-4$ & $.00311 * * *$ \\
\hline Price change $t-5 \ldots \ldots \ldots \ldots \ldots \ldots$ & $.00259 * * *$ \\
\hline \multirow{3}{*}{ 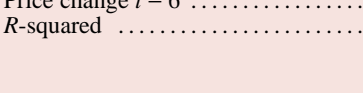 } & $.00201 *$ \\
\hline & .33 \\
\hline & Price changes on flows \\
\hline Constant . & $.82 * *$ \\
\hline Flows $t \ldots$. & $70.58 * * *$ \\
\hline Flows $t-1 \ldots$ & $-24.79 * * *$ \\
\hline Flows $t-2 \ldots \ldots$ & $-23.15 * * *$ \\
\hline Flows $t-3 \ldots \ldots \ldots \ldots \ldots \ldots \ldots \ldots$ & $-18.98 * * *$ \\
\hline Flows $t-4 \ldots \ldots \ldots \ldots \ldots \ldots \ldots$ & -5.82 \\
\hline Flows $t-5 \ldots \ldots \ldots \ldots \ldots \ldots \ldots$ & 7.64 \\
\hline Flows $t-6 \ldots \ldots \ldots \ldots \ldots$ & -.09 \\
\hline$R$-squared $\ldots \ldots \ldots \ldots \ldots \ldots \ldots \ldots$ & .57 \\
\hline
\end{tabular}

NotE. Flows are defined as monthly net new cash flows to domestic equity mutual funds as a percentage of smoothed stock market capitalization (see appendix text for details). Price change is defined as the monthly percent change in the Wilshire 5000 index. For the dependent variable, regressions use monthly data from July 1984 through August 2000.

* Significant at 10 percent level.

** Significant at 5 percent level.

*** Significant at 1 percent level.

for their trend) are driven only by information $I(t)$ each month. The information hypothesis model is

(2a) $\quad f(t)=k_{d}+d_{I} I(t)+d_{1} f(t-1)+\ldots+d_{6} f(t-6)$

(2b) $R(t)=k_{h}+h_{I} I(t)$.

An analyst who regresses price changes on current and lagged flows, as in equation $1 b$, when the true model is given by equations $2 a$ and $2 b$, would estimate coefficients that are in fact spurious. Assume for convenience that the analyst uses only one lag of flows in the regression, estimating

$$
R(t)=k_{c}+c_{0} f(t)+c_{1} f(t-1) .
$$

Assume further that only one lag is needed, so that $d_{2}=d_{3}=\ldots=d_{6}=0$. Substituting for $f(t)$ from equation $2 \mathrm{a}$, the regression equation above can be rewritten as

$$
R(t)=\left[k_{c}+c_{0} k_{d}\right]+\left[c_{0} d_{2}\right] I(t)+\left[c_{1}+c_{0} d_{1}\right] f(t-1) .
$$

Comparing this relation with the true relation, given in equation $2 b$, we see that, with enough data, the parameter estimates $k_{c}, c_{0}$, and $c_{1}$ will be related to the true parameters $k_{h}$ and $h_{I}$ by the system of equations

$$
\begin{aligned}
k_{c}+c_{0} k_{d} & =k_{h} \\
c_{0} d_{2} & =h_{I} \\
c_{1}+c_{0} d_{1} & =0 .
\end{aligned}
$$

Our hypothetical analyst would falsely conclude that flows push up current price changes (because $c_{0}$ would be positive) but depress future price changes (because $c_{1}$ would be negative). The same sort of analysis can be applied to regressions of the form in equation 1a to show that the analyst would, falsely, conclude that investors were following a feedback trading strategy. Thus the results in table A.1 cannot be taken as evidence of the price pressure hypothesis because they are entirely consistent with the information hypothesis.

If the true model were actually given by the information hypothesis, specified by equations $2 \mathrm{a}$ and $2 \mathrm{~b}$, the correct estimation strategy would be to proxy this month's information $I(t)$, which is unobserved, by observed price changes, $R(t)$, while at the same time controlling for the trend in mutual fund flows. The results of these regressions are shown in table A.2. Note that the effect of contemporaneous price changes declines somewhat from the first half of the sample period to the second. This result is consistent with the correlation coefficient shown in chart 13 (top panel), which trends downward over time.

\section{Granger Causality Tests}

Although the results in tables A.1 and A.2 are consis-

\begin{tabular}{|c|c|c|c|}
\hline \multirow{2}{*}{$\begin{array}{l}\text { Independent } \\
\text { variable }\end{array}$} & \multicolumn{3}{|c|}{ Coefficient } \\
\hline & $\begin{array}{c}\text { January } 1984- \\
\text { August } 2000\end{array}$ & $\begin{array}{c}\text { January } 1984- \\
\text { May } 1992\end{array}$ & $\begin{array}{c}\text { June } 1992- \\
\text { August } 2000\end{array}$ \\
\hline Constant & -0001 & -0036 & 0285 *** \\
\hline Price change $t$ & $.0078 * * *$ & $.0084 * * *$ & $.0071 * * *$ \\
\hline Flows $t-1$.. & $.3688 * * *$ & .2200 *** & $.5079 * * *$ \\
\hline Flows $t-2$ & $.2849 * * *$ & $.2817 * * *$ & $.2201 * * *$ \\
\hline Flows $t-3$ & $2010 * * *$ & $.2533 * * *$ & .0692 \\
\hline Flows $t-4$ & .0669 & .0514 & .1344 \\
\hline Flows $t-5$ & -.0149 & .0519 & $-.1890 * *$ \\
\hline Flows $t-6$ & -.0294 & .0116 & -.1000 \\
\hline$R$-squared . & .79 & .77 & .61 \\
\hline
\end{tabular}
tent with the information hypothesis, they do not rule out the price pressure hypothesis. We now test directly the proposition that flows to equity mutual

A.2. Regressions of flows on price changes and lagged flows

Note. The dependent variable is the monthly net new cash flow to domestic equity mutual funds as a percentage of smoothed market capitalization (see appendix text for details). Price change is defined as the monthly percent change in the Wilshire 5000 index.

** Significant at 5 percent level.

*** Significant at 1 percent level. 
funds statistically cause equity market price changes using Granger causality tests. If flows can help predict equity price changes, they would be said to Granger-cause equity market price changes. Our goal, in essence, is to test statistically whether the negative correlation coefficient between current flows and future price changes, shown in chart 13 (lower panel), is statistically significant. The Granger test requires estimating two regression equations: an unrestricted equation (UR) that regresses current price changes on lagged price changes and lagged flows and a restricted equation ( $R$ ) that regresses current price changes on lagged price changes only, excluding lagged flows. We then use an $F$-test to test the hypothesis that the coefficients on the lagged flows in the unrestricted equation are jointly equal to zero. Intuitively, if excluding flows affects our ability to explain price changes, then flows must determine, at least in part, price changes. More formally, the equations to fit are

$$
\begin{aligned}
& R(t)=x_{0}+\sum_{i=1}^{n} x_{i} R(t-i)+\sum_{j=1}^{m} y_{j} f(t-j) \\
& R(t)=x_{0}^{*}+\sum_{i=1}^{n} x_{i}^{*} R(t-i) .
\end{aligned}
$$

The test results are sensitive to the number of lags (the parameters $m$ and $n$ ) used and the time periods over which the equations are estimated. In the upper panel of table A.3 are the results of using six months and twelve months of lags (for both flows and price changes) over the entire sample period as well as over the first and second halves of the period. The table gives the $F$-statistic for the hypothesis that $y_{1}=$ $y_{2}=\ldots=y_{n}=0$, that is, that flows do not cause price changes. Also given is the long-term effect of flows on price changes, which is simply the sum of the coefficients $y_{i}$ in the unrestricted equation.

We can reject the hypothesis that flows cause price changes for all but one specification, the specification with six lags estimated over the earlier half of the sample period. Because mutual funds were a much smaller part of the equity market in this earlier period, this single result seems somewhat anomalous and cannot be taken as strong evidence for the price pressure hypothesis. Further, tests using the second half of the period, when mutual funds were a larger part of the equity market, indicate that flows do not cause price changes. Consistent with chart 13 (lower panel), the long-term effects are negative, although, again, in most cases they are not statistically different from zero. These results do not provide compelling support for the price pressure hypothesis. Of course, the price pressure effect may play out quite rapidly, with prices rising and then falling within a matter of days, so that with our monthly data we are unable to detect it. However, such a scenario cannot explain the strong simultaneous correlation between flows and price changes that we do observe in the data. Our results indicate that this monthly correlation cannot be ascribed to the price pressure hypothesis.

In the same way that we tested whether flows caused price changes, we can test whether price changes cause flows; that is, we can test the proposition that households are following, in the aggregate, a feedback trader strategy. The lower panel of table A.3 displays the results of Granger causality tests of the effect of price changes on flows. For all specifications we reject the hypothesis that flows cause price changes. Thus, the evidence does not

\begin{tabular}{|c|c|c|c|c|c|c|}
\hline \multirow{2}{*}{ Number of lags } & \multicolumn{2}{|c|}{ January 1984-August 2000} & \multicolumn{2}{|c|}{ January 1984-May 1992} & \multicolumn{2}{|c|}{ June 1992-August 2000} \\
\hline & $F$-statistic & Effect & $F$-statistic & Effect & $F$-statistic & Effect \\
\hline \multirow{4}{*}{$\begin{array}{l}\text { Six } \ldots . . . \\
\text { Twelve }\end{array}$} & \multicolumn{6}{|c|}{ Flows on price changes } \\
\hline & $\begin{array}{l}.97 \\
.48\end{array}$ & $\begin{array}{l}-3.33 \\
-1.49\end{array}$ & $\begin{array}{l}2.53 * * \\
1.18\end{array}$ & $\begin{array}{l}-16.48 \\
-10.63\end{array}$ & $\begin{array}{l}1.42 \\
1.13\end{array}$ & $\begin{array}{l}-14.81 \\
-21.45\end{array}$ \\
\hline & \multicolumn{6}{|c|}{ Price changes on flows } \\
\hline & $\begin{array}{r}.74 \\
1.06\end{array}$ & $\begin{array}{l}-.0035 \\
-.0013\end{array}$ & $\begin{array}{l}1.65 \\
1.21\end{array}$ & $\begin{array}{l}-.0064 \\
-.0084\end{array}$ & $\begin{array}{r}.79 \\
1.06\end{array}$ & $\begin{array}{l}.0001 \\
.0072\end{array}$ \\
\hline $\begin{array}{l}\text { Note. The upper panel gives the } F \text {-sta } \\
\text { do not cause price changes and the sur } \\
\text { effect of flows on price changes; the lo } \\
\text { hypothesis test that price changes do } \\
\text { computed coefficients of the effect of pri }\end{array}$ & $\begin{array}{l}\text { for the hyp } \\
\text { the comput } \\
\text { anel gives } \\
\text { ause flows } \\
\text { anges on flo }\end{array}$ & $\begin{array}{l}\text { st that flo } \\
\text { ients of } t \\
\text { istic for } t \\
\text { sum of } t \\
\text { are defin }\end{array}$ & $\begin{array}{l}\text { as monthly n } \\
\text { of smoothed } \\
\text { change is def } \\
\text { ** Hypoth }\end{array}$ & $\begin{array}{l}\text { ash flows to } \\
\text { arket capita } \\
\text { he monthly } 1 \\
\text { ted at the } 5\end{array}$ & $\begin{array}{l}\text { equity mut } \\
\text { see append } \\
\text { hange in the } \\
\text { onfidence l }\end{array}$ & $\begin{array}{l}\text { as a percentage } \\
\text { or details). Price } \\
5000 \text { index. }\end{array}$ \\
\hline
\end{tabular}

A.3. Granger causality tests of the effect of flows on price changes and price changes on flows 
suggest that households are, in the aggregate, following a feedback trader strategy.

Financial commentators often claim that equity mutual funds play a large role in the domestic stock market. Some claim that the long bull market of the 1990s was driven by cash flows to mutual funds, while others claim, to the contrary, that cash flows to equity funds drive up the stock market only temporarily, after which the market gradually readjusts to its general market value. Underlying both views is the idea that mutual fund investors are somehow less savvy or less informed about equity markets than other investors (for example, institutional investors or individuals who own stocks directly). Our results do not support this idea. We find that mutual fund investors do not lag the market; that is, they do not invest more in equity funds in the months following a particularly positive performance by the market. Nor do we find evidence that equity fund flows statistically cause market price changes, by either temporarily or permanently pushing stock prices above their market values. We conclude that mutual fund investors react to incoming news and other factors that influence the valuations of stocks in a manner similar to that of other market participants. 